\title{
AMERICAN FOREIGN POLICY AT THE END OF THE XIX - EARLY XX CENTURIES AND SOCIAL DARWINIST IDEOLOGY
}

(C) 2017

Mukhataev Pavel Nicolaevich, teacher of history and social theory Secondary School №7 of Samara Urban Okrug (Samara, Russian Federation)

\begin{abstract}
This paper presents a historiographical review of American foreign policy, as well as analysis of the causes of the emergence of American expansionist paradigm in the late XIX - early XX centuries. Soviet historians give us an idea about the economic aspect of events in the U.S. during the specified period. However, foreign scientists have multidimensional view on the events. A. Schlesinger as one of the most popular authors insisted on the secondary importance of economic reasons for an active foreign policy of the United States, indicating that political reasons were of paramount importance. Social Darwinism, as a phenomenon that could shape foreign policy is considered by historians indirectly. In the Russian-Soviet historiography Social Darwinism is denoted as a factor that influences policy indirectly. American historiography considers the subject of our study more wholly, but in the context of the analysis of the liberal ideology. The author points to the role of ideological reasons for the American administration's foreign policy decision-making. The paper is an attempt to find out whether there was a connection between foreign policy and the Social-Darwinist discourse, which can be traced in political, economic and intellectual elites of American society at the turn of the century.

Keywords: Social-Darwinism; foreign policy of United States of America in late XIX - early XX centuries; G. Spenser; A. Beverige; A. Carnegie; C. Schurz; Ch. Conant; A. Mahan; F. Turner; T. Roosevelt; Anglo-Saxon race; H. Zinn; A. Schlezinger; B. Kozenko; A. Raskin; G. Musikhin; A. Gofman; expansionism.
\end{abstract}

УДК 94(595)

Статья поступила в редакцию 25.09.2017

\section{КОЛОНИАЛЬНЫЕ ИМПЕРИИ ПОСЛЕ 1945 ГОДА: ВЗГЛЯД ИЗ США}

(C) 2017

Буранок Сергей Олегович, доктор исторических наук, профессор кафедры всеобщей истории, права и методики обучения

Самарский государственный соџиально-педагогический университет (г. Самара, Российская Федераџия)

Аннотация. Исследования колониальной проблематики в условиях холодной войны невозможны без привлечения прессы участников данных процессов. Изучение прессы США даст возможность более глубоко и конкретно осветить американские представления о практических подходах в международных отношениях в условиях трансформации миропорядка после Второй мировой войны. Анализ прессы показал, что в течение 1945 г. в американском общественном дискурсе происходила смена приоритетных подходов: рузвельтовский план ликвидации колониальных империй постепенно заменялся планами сохранения и использования колониальных империй и их опыта для решения новых задач внешней политики США.

Сразу после завершения Второй мировой войны пресса США начинает процесс пересмотра своего отношения к колониальной теме. СМИ США явно отходят от позиций критицизма и переходят к более глубокому и всестороннему анализу как самой системы в целом, так и британского опыта управления колониями, открыто признавая, что в этом вопросе исторические связи, опыт решения конфликтов и управления местными элитами может оказаться более полезным, чем верность абстрактным принципам. В конце 1945-1946 гг. наблюдаются тенденции в прессе США по изменению с позиции заинтересованного наблюдателя на активного участника колониальной проблемы.

Ключевые слова: колониализм; колонии; пресса США; Британская империя; национальные движения в колониях; международные отношения; общественное мнение; холодная война; формирование биполярной системы; американские журналисты; колониальные империи; колониальная политика; национальный вопрос.

Вопросы о перспективах колониальной системы, о переходе в эпоху постколониализма, о возможности применения опыта колониальных империй были одними из наиболее популярных и весьма дискуссионных в американском обществе на протяжении новейшей истории $[1$, р. $10-15 ; 2$, р. $281 ; 3$, р. 1-9; 4, p. $280 ; 5$, p. 11]. Особенно он актуализировался в периоды после Великой войны (1918-1922) [5, р. 12] и на завершающем этапе Второй мировой войны (19441945 гг.) [6, с. 9; 7, с. 116]. Изучение периодической печати США позволит определить более широкий набор моделей решения колониального вопроса, чем анализ только мнения экспертного сообщества и дипломатического корпуса, а главное, даст возможность более глубоко и конкретно осветить американские представления о практических подходах в международных отношениях в условиях трансформации миропорядка после Второй мировой войны.

В период 1944-1945 гг. большинство наиболее авторитетных и читаемых в США журналистов сконцентрировались на европейской политике, которая представлялась и в Белом доме, и в госдепартаменте, и в СМИ краеугольным камнем американской внешней политики. Поэтому как взгляды на колониальную систему, так и модели решения колониального вопроса формировались в США, с одной стороны, под явным влиянием европейского фактора международных отношений: Липпман, Линдли, Уэллс, 
Сульцбергер оперировали для доказательства необходимости трансформации или ликвидации колониальных империй целым набором тезисов, отсылающих к европейской политике (европейские державы получат экономическую выгоду от ликвидации колоний; Европа получит от США экономическую помощь; Европа использует непопулярные и устаревшие методы управления). Так или иначе, но в центре колониального вопроса оставалась европейская политика США, а принципы Атлантической хартии, прав и свобод колониальных народов, самоопределения для наций выглядели у журналистов лишь средством формирования новой системы отношений между США и Европой.

С другой стороны, в статьях уже упомянутых политиков и журналистов просматривается другой фактор влияния на выработку подходов к колониальной теме: это внимание Советского Союза к национально-освободительным движениям в Азии и Африке. Особенно быстро растущее влияние этого фактора прослеживается в публикациях с осени 1945 г., когда и Линдли, и Липпман начинают обсуждать негативные эффекты деколонизации, указывая, что распад империй, безусловно, откроет для США новые рынки, но, одновременно, «политический вакуум» в колониях может быть заполнен коммунистами, либо, как вариант другого сценария, радикальный процесс освобождения колоний от Европы неминуемо скажется на экономике всего региона, буквально подтолкнув европейцев (сначала в экономическом, потом и в морально-политическом плане) к коммунизму [8, p. 4].

В американском общественном дискурсе сразу после завершения Второй мировой войны начинает складываться сразу несколько новых подходов к оценке перспектив колониальной системы. Первый подход: сохранение колониальных империй, особенно в ключевых точках послевоенного мира: Ближний Восток, Индокитай, Северная Африка. Второй подход: сохранение Британской колониальной империи, способной (при поддержке США) контролировать Средиземноморье, Ближний Восток, Юго-Восточную Азию, решая тем самым сразу две задачи: сырьевое обеспечение американской экономики, контроль над повстанческими и национально-освободительными силами. Третий подход: замена колониальных империй американским военным присутствием для выполнения тех же задач. Но второй и третий вариант неизбежно актуализировали в американском общественном и академическом дискурсе ещё более сложные вопросы: какую форму военных операций США потребует такого рода поддержка, какая должна быть конфигурация военно-политического планирования, какова глобальная перспектива возможного военного вмешательства США в процессы в Юго-Восточной Азии, на Ближнем Востоке. Иными словами, в самом конце 1945 г. ведущие журналисты США по колониальной теме подошли к постановке чрезвычайно многогранной проблемы: об историческом моделировании асимметричных конфликтов в странах третьего мира в контексте начинающейся холодной войны и в контексте опыта глобальных колониальных империй.

Данные подходы в 1945 г. находились лишь в стадии формирования. Их широкое обсуждение в госу- дарственных структурах, экспертном сообществе и СМИ придется уже на 1946-1949 гг. Но каждая из новых моделей потребовала нового идейного фундамента для обсуждения, нового осмысления экономического, социального и гуманитарного знания, нового анализа колониального опыта.

Осенью - зимой 1945 г. ведущие журналисты США не считали свою державу прямым соперником Великобритании в странах третьего мира. В газетных публикациях существовала и обладала определенной популярностью идея отказаться от прямого вмешательства в европейские дела: широко обсуждался вариант сохранения ключевых сфер влияния: советской, британской и французской, возможно, даже голландской и бельгийской. Наиболее точно эту идею обосновал У. Липпман, который считал, что нужно сохранить хрупкий баланс между политикой самоопределения (от нее никто из серьезных журналистов и экспертов не предлагал отказываться) и политикой деколонизации. Липпман предлагал своеобразное решение этой дилеммы, назвав его «упорядоченной деколонизацией», при которой демонтаж колониальных систем не повредит отношениям США со своими европейскими союзниками $[9, \mathrm{p} .3]$.

Липпман предлагал сосредоточиться на более важном вопросе: «основной проблемой Америки является то, что во всех регионах мира, где существует опасный международный беспорядок, британское влияние на эти регионы является более древним, более прямым, более доверенным, чем американское» [10]. Новый рецепт Липпмана выглядел весьма привлекательным в общем контексте американского общественного дискурса: не самим решать проблемы Индонезии, Малайи, Ближнего Востока и Индии, а через взаимодействие с существующей, как писал журналист, «имперской властью». Так, американцы не откажутся от принципов Атлантической хартии и одновременно продемонстрируют европейским союзникам свою поддержку и понимание их колониальных интересов. Все чаще в публикациях американских журналистов звучат слова «порядок» и «стабильность» в странах третьего мира, вместо немедленной свободы и самоопределения для африканских и азиатских народов.

Причин таких перемен в колониальной дискуссии несколько. Во-первых, в конце 1945 - начале 1946 г. национальные движения в колониях, особенно в Индокитае и Индонезии, заметно активизировались. Вовторых, все большую опасность (в глазах американских журналистов) приобретало сближение (и в идейном, и в практико-политическом плане) антиколониальных сил Азии с советским блоком. В-третьих, очевидная слабость европейских держав в колониях позволяла американским комментаторам и экспертам довольно свободно рассуждать о будущей (причем в ближайшей перспективе) роли США: от арбитра колониальных споров до участника силовых акций в колониях $[10$, p. 8$]$.

Решение этого нового вопроса все больше рассматривалось участниками дискуссии как особая форма поддержки для Западной Европы: США сохранят влияние на процессы деколонизации в регионах, где порядок и стабильность возможно сохранить уже без европейского вмешательства, и вместе с тем 
поддержат колониальные системы в регионах, где они являются гарантом стабильности.

В конце 1945-1946 гг. наблюдаются тенденции в прессе США по изменению с позиции заинтересованного наблюдателя на активного участника колониальной проблемы. Наибольшее внимание журналистов было сосредоточено на Ближнем Востоке. Общий настрой американских редакторов и комментаторов заключался в том, что они признавали: для чтобы поддерживать порядок и стабильность на Ближнем Востоке, необходимы конкретные действия со стороны США, но при этом указывалось, что Великобритания и Франция обладают более длительной историей своих интересов в этом регионе, более солидным опытом, большими знаниями о Ближнем Востоке, следовательно, имеют законное право (в глазах мировой и в том числе американской общественности) на вмешательство [11, р. 2, 6]. По этому поводу Барнет Новер, один из редакторов «Washington Post», заявил, что «разрушение или внезапный роспуск британской империи был бы серьезным ударом по безопасности США, демократии и надежде на получение упорядоченного мира» [12, р. 4].

Таким образом, на первый план в начале 1946 г. выходит не демонтаж колониальной системы, как противоречащей принципам Атлантической хартии, a ее глобальная перестройка, с сохранением (сугубо временным) доминирующего положения Великобритании или Франции в регионах, где США не смогу сразу обеспечить стабильность. Подобное изменение подходов настораживало американских экспертов: владелец «New York Times» А. Сульцбергер писал: «Европа нам не доверяет. Часто можно услышать, что Соединенные Штаты непопулярные, наследуют методы XIX века» [13, p. 5].

Следовательно, можно утверждать, что сразу после завершения Второй мировой войны пресса США начинает процесс пересмотра своего отношения к колониальной теме. СМИ США явно отходят от позиций критицизма и переходят к более глубокому и всестороннему анализу как самой системы в целом, так и британского опыта управления колониями, открыто признавая, что в этом вопросе исторические связи, опыт решения конфликтов и управления местными элитами может оказаться более полезным, чем верность абстрактным принципам.

\section{СПИСОК ЛИТЕРАТУРЫ:}

1. Postcolonialism: Critical concepts in literary and cultural studies. Ed. by D. Brydon. L.; N.Y., 2000. Vol. 1-5. Vol. 1. 440 p.

2. Ashcroft B., Griffiths G., Tiffin H. The Empire Writes Back: Theory and Practice in Post-Colonial Literatures. L., N.Y.: Routledge, 2010. 296 p.

3. James-Chakraborty K. Beyond Postcolonialism: New Directions for The History of Nonwestern Architecture // Frontiers of Architectural Research. 2014. № 3. P. 1-9.

4. Cooper F.Colonialism in Question: Theory, Knowledge, History. Berkeley, Los Angeles, London, 2005. $328 \mathrm{p}$.

5. Tompkins E.B. Anti-Imperialism in the United States: The Great Debate 1890-1920. Philadelphia, 1970. 352 p.

6. Егорова Н.И. Холодная война в освещении новейшей российской историографии // Электронный научно-образовательный журнал История. 2014. № 7 (30). C. 9.

7. Егорова Н.И. «Новая история холодной войны» в современных зарубежных исследованиях // Новая и новейшая история. 2009. № 4. С. 116-129.

8. Washington Post. 1945.10.30. 42 p.

9. Washington Post. 1945.04.19. 44 p.

10. Washington Post. 1945.05.22. 40 p.

11. Washington Post. 1945.12.07. 42 p.

12. Washington Post. 1945.10.27. 42 p.

13. New York Times. 1946.01.23. 56 p.

Исследование выполнено за счет гранта Российского научного фонда (проект № 17-78-20029).

\title{
COLONIAL EMPIRE AFTER 1945: A VIEW FROM THE USA
}

(C) 2017

\author{
Buranok Sergey Olegovich, doctor of historical sciences, \\ professor of World History, Law and Methods of Teaching Department \\ Samara State University of Social Sciences and Education (Samara, Russian Federation)
}

Abstract. No research in the colonial system issues during the Cold War would be complete without studying the press of the participating parties. In order to give a detailed analysis of the international relationships in terms of the global transformations from the American point of view, the author draws relevant newspaper articles published after the World War II. The results have shown changes to priority schemes as viewed in American social discourse during 1945. Roosevelt's plan for the dismantling of the colonial empires was gradually replaced with less radical plans, which presupposed using the colonial experience for foreign policy of the USA. Immediately after the end of the Second World War, the US press began to re-examine its attitude towards the colonial issue. The US media were clearly shifting from criticism to a deeper and more comprehensive analysis of both the system itself as a whole and British colonial management experience, openly acknowledging that in this context, historic ties, conflict resolution and local elite management experience may have turned out to be more useful than loyalty to abstract principles. At the end of 1945-1946 there were tendencies in the US press to change from the position of an interested observer to an active participant in the colonial problem.

Keywords: colonialism; colonies; US press; British Empire; national movements in colonies; international relations; public opinion; Cold War; formation of bipolar system; American journalists; colonial empires; colonial politics; national question. 